\title{
Characterization of Testicular
}

\section{Angiotensin-Converting Enzyme before and after Semen Cryopreservation and in the Acrosome Reaction of Spermatozoids of Nelore Bulls}

\author{
Ricardo G. Almeida1, Fabio J. C. Faria1, Fernando H. G. Furtado', Elisvânia F. Santos ${ }^{2}$, Deiler S. Costa ${ }^{*}$ \\ ${ }^{1}$ Lab of Assisted Reproduction-FAMEZ, Federal University of Mato Grosso do Sul, Campo Grande, Brazil \\ ${ }^{2}$ Institute of Biology-INBIO, Federal University of Mato Grosso do Sul, Campo Grande, Brazil \\ Email: ^deilercosta@yahoo.com.br
}

How to cite this paper: Almeida, R.G., Faria, F.J.C., Furtado, F.H.G., Santos, E.F. and Costa, D.S. (2019) Characterization of Testicular Angiotensin-Converting Enzyme before and after Semen Cryopreservation and in the Acrosome Reaction of Spermatozoids of Nelore Bulls. Agricultural Sciences, 10, 518-529.

https://doi.org/10.4236/as.2019.104041

Received: March 22, 2019

Accepted: April 16, 2019

Published: April 19, 2019

Copyright $\odot 2019$ by author(s) and Scientific Research Publishing Inc. This work is licensed under the Creative Commons Attribution International License (CC BY 4.0).

http://creativecommons.org/licenses/by/4.0/

\begin{abstract}
The aim of this study was to characterize the testicular isoform of angiotensin-converting enzyme (tACE) before and after semen cryopreservation, and in the acrosome reaction of sperm from Nelore bulls in vitro. Ejaculates of 10 sexually mature Nelore bulls were used. After semen was collected, $1.0 \mathrm{~mL}$ of the ejaculate was used for the analysis and the rest was subjected to cryopreservation. Fresh semen before freezing, and frozen/thawed semen were centrifuged twice and the pellet was resuspended intyrode's albumin lactate pyruvate (TALP). Thereafter, $100 \mu \mathrm{L}$ aliquots containing $100 \times 10^{6}$ spermatozoa were prepared. Aliquots of samples were used for western blot analysis, subjected to capacitation, and thereafter, acrosome reaction assays were performed in vitro. With the help of an anti-ACE monoclonal antibody, a 100 $\mathrm{kDa}$ protein band was identified in the spermatozoa of Nelore bulls. Cryopreservation reduced the intensity of the protein bands obtained by western blot assay to less than half of that observed prior to freezing $(P<0.05)$. Inhibition of ACE by captopril $(10 \mu \mathrm{M})$, decreased the percentage of capacitated spermatozoa with a positive acrosome reaction $(P<0.05)$, indicating the involvement of ACE in these processes. It is concluded that tACE can be found in the spermatozoa of Nelore bulls, and cryopreservation process decreases the intensity of bands of this enzyme; and that the inactivation of tACE reduces the capacity of spermatozoa to undergo the acrosome reaction.
\end{abstract}




\section{Keywords}

Bovine, Semen, Proteomic

\section{Introduction}

Angiotensin-converting enzyme (ACE) is a zinc-dependent metalloprotease, which is anchored to the plasma membrane and exists in two isoforms. A somatic form (sACE150 - $180 \mathrm{kDa}$ ) is found in various organs and is involved in the control of blood pressure via the renin-angiotensin-aldosterone system. sACE converts inactive angiotensin I into angiotensin II, a potent vasoconstrictor that also stimulates the release of the hormone aldosterone, which induces sodium retention and increases blood pressure. In addition, it enhances this effect by inhibiting the action of the vasodilator bradykinin [1] [2] [3] [4] [5].

The second isoform is of lower molecular weight $(110 \mathrm{kDa})$, although transcribed by the same gene, and is found exclusively in male germ cells; therefore, it was designated as a testicular isoform (tACE). This isoform is not expressed in animals before puberty, which suggests that hormonal stimulation is required for its synthesis [3]. Hypophysectomized rats do not express tACE before puberty; however, animals that receive testosterone, follicle stimulate follicle-stimulating hormone (FSH), and luteinizing hormone (LH) soon after pituitary withdrawal can synthesize the enzyme, indicating the need for reproductive hormones in the expression of tACE [6].

tACE has an important function in the fertilization of the egg by sperm. In experiments with ACE-knockout mice, no changes in the number or morphology of sperm were observed, although they displayed defects when binding to the zonaepellucidae [7]. For fertilization to occur, proteins such as TESP5 and $\mathrm{PH}-20$, which are anchored to the spermatozoa by glycosylphosphatidylinositol (GPI), need to be released, and this is one of the roles performed by ACE, and explains why ACE-knockout mice have impaired fertility [8].

Part of ACE is released from spermatozoa during capacitation [9], indicating that it is also involved in this process; however, its role remains unclear. Gur et al. [10] showed that the activity of angiotensin II on spermatozoa capacitation and the acrosome reaction involves the AT1 receptor. This demonstrates the indirect action of ACE in these processes, as the enzyme is responsible for the conversion of angiotensin I into angiotensin II.

Several studies have revealed ACE activity in human [11], canine [2], swine [12], equine [13], and rodent semen [14]. In a study, Costa and Thundathil [15] observed ACE activity in the semen of Holstein bulls, making ACEa candidate protein marker of bovine fertility. Thus, the present study was carried out to verify the immunolocalization of ACE in spermatozoa, to compare its expression pattern before and after cryopreservation, and to determine its importance in sperm capacitation in Nelore bulls. 


\section{Materials and Methods}

\subsection{Animals and Semen Collection}

Semen samples from 10 sexually mature Nelore bulls (Bos taurusindicus) were used. Semen was collected by the artificial vagina technique in an artificial insemination center. Only ejaculates with motility greater than $70 \%$ and vigour greater than three were used. Sperm motility $(0 \%-100 \%)$ and sperm vigour (score from 0 to 5 ) were subjectively assessed by the same technician in at least four fields in each sample, and the results were expressed in average of the fields.

All international guidelines for the care and use of animals for scientific purposes were followed in this experiment.

\subsection{Cryopreservation of Semen}

An ejaculate sample from each bull was diluted in tris-yolk buffer (tris $2.42 \%$, citric acid $1.36 \%$, fructose $1.0 \%$, glycerol $7.0 \%$, egg yolk $20.0 \%$, and gentamic in $0.7 \%)$ at a concentration of $50 \times 10^{6}$ spermatozoids $/ \mathrm{mL}$, and packed in $0.5 \mathrm{mLvials}$. Samples were frozen using a TK 4000 programmable portable semen cryopreservation system (TK Equipamentospara Reprodução, Uberaba, Brazil). In this system, the cooling rate was $0.25^{\circ} \mathrm{C} / \mathrm{min}$ up to $5^{\circ} \mathrm{C}$, where it remained constant for 5 hours. Then, the freezing rate was $-15^{\circ} \mathrm{C} / \mathrm{min}$ from $5^{\circ} \mathrm{C}$ to $-80^{\circ} \mathrm{C}$, and then from $-10^{\circ} \mathrm{C} / \mathrm{min}$ to $-140^{\circ} \mathrm{C}$. Thereafter, the vials were racked and stored in cryogenic cylinders at $-196^{\circ} \mathrm{C}$.

\subsection{Preparation of Spermatozoid Pellets}

In order to prepare the fresh semen pellet, a $1.0 \mathrm{~mL}$ sample was withdrawn immediately after the ejaculate was collected and centrifuged twice at $700 \mathrm{~g}$ for 30 min (at room temperature) in Tyrode's albumin lactate pyruvate medium (TALP [16]) to remove the seminal plasma. The supernatant was discarded and the pellet formed was used for the subsequent analyses.

To prepare a frozen/thawed semen pellet, 48 hours after of storage in cryogenic tanks, 10 vials were thawed in a water bath at $37^{\circ} \mathrm{C}$ for $30 \mathrm{~s}$. Then, the semen was placed in the same tube and centrifuged twice at $700 \mathrm{~g}$ for 30 min with TALP to remove the diluent. The supernatant was discarded and the pellet formed was used for subsequent analyses.

\section{Western blot}

To detect ACE in Nelore bull spermatozoa, the pellet concentration was determined after centrifugation with TALP, and protein was extracted from $100 \mu \mathrm{L}$ aliquots containing $100 \times 10^{6}$ spermatozoa with $25 \mu \mathrm{L}$ Laemmli buffer (4\% SDS, $20 \%$ glycerol, $10 \%$ DTT, $0.004 \%$ bromophenol blue, and $0.125 \mathrm{M}$ Tris $\mathrm{HCl}, \mathrm{pH}$ 6.8) and heating at $100^{\circ} \mathrm{C}$ for $5 \mathrm{~min}$. The samples were then centrifuged at $11,200 \mathrm{~g}$ for $5 \mathrm{~min}$.

The supernatant (protein extract) was subjected to SDS-polyacrylamide gel electrophoresis (SDS-PAGE 10\%) to separate the proteins according to their 
molecular weights. After $1 \mathrm{~h}$ at a constant electric current of $100 \mathrm{~V}$, the proteins traversed the entire length of the gel. The gel was then carefully removed from the cassette and submerged in $20 \%$ ethanol for $10 \mathrm{~min}$ to increase transfer efficiency. Proteins were transferred from the gel to a nitrocellulose membrane by electrophoresis in a sandwich system with transfer buffer (25 mM Tris, $0.2 \mathrm{M}$ glycine, and $20 \%$ methyl alcohol, $\mathrm{pH} 8.5$ ), at a constant voltage of $350 \mathrm{~mA}$. The resulting nitrocellulose membranes were stained with $0.2 \%$ ponceau in acetic acid to determine the effectiveness of the electrotransfer. Subsequently, nonspecific binding sites were blocked with $3 \%$ skimmed milk powder, diluted in tris-buffered saline + tween 20 medium (TTBS), for $60 \mathrm{~min}$ at room temperature. The membranes were then incubated (overnight at $4^{\circ} \mathrm{C}$ ) with the primary antibody (anti-ACE, clone 2E2, Millipore , 1:5000 in TTBS). Following overnight incubation the membranes were washed three times in TTBS, and incubated with secondary antibody (goat anti-mouse IgG, HRP conjugate, Millipore, $1: 10,000$ in TTBS) for $1 \mathrm{~h}$ at room temperature. After washing three times with TTBS, the protein bands were identified by chemiluminescence [17].

To confirm that all samples contained the same amount of protein, another gel was prepared using the same samples, and a further western blot was performed using a monoclonal anti- $\beta$-tubulin antibody [18]. The pixel density of the protein bands was compared with the software Image J 1.40 (ranging between $0=$ anechoic and $255=$ hyperechoic); the more protein present in the sample, the more hypoechoic the image and the lower the number of pixels.

ACE was detected in seminal plasma by adding $25 \mu \mathrm{L}$ of Laemmli buffer to $100-\mu \mathrm{L}$ aliquots of plasma diluted in TALP (1:50) and heated at $100^{\circ} \mathrm{C}$ for $5 \mathrm{~min}$ to extract protein. Then, the samples were centrifuged at 11,200 $\mathrm{g}$ for $5 \mathrm{~min}$ and the supernatant was used for western blotting, with the same methodology described for spermatozoa.

\subsection{Testing of Sperm Capacitation}

Aliquots of $50 \mu \mathrm{L}$ containing $200 \times 10^{6}$ spermatozoa were used for each of the following treatments for each bull: control group $(50 \mu \mathrm{L}$ of semen $+50 \mu \mathrm{L}$ of SP-TALP), heparin group $(50 \mu \mathrm{L}$ of semen $+49 \mu \mathrm{L}$ of SP-TALP $+1.0 \mu \mathrm{L}$ of heparin $100 \mu \mathrm{g} / \mu \mathrm{L})$, captopril + heparin group $(50 \mu \mathrm{L}$ of semen $+49 \mu \mathrm{L}$ of SP-TALP $+1.0 \mu \mathrm{L}$ of heparin $100 \mu \mathrm{g} / \mu \mathrm{L}+10 \mu \mathrm{M}$ captopril). The samples were incubated in a $\mathrm{CO}_{2}$ incubator at $39^{\circ} \mathrm{C}$ for $4 \mathrm{~h}$. Sperm motility and vigour were evaluated every hour in each experimental group to evaluate whether capacitation occurred at a similar time for each animal evaluated.

\subsection{Induction of Acrosome Reaction in the Capacitated Spermatozoids}

After 4-h incubation, an aliquot of each treatment was incubated for a further 30 min with L- $\alpha$-lysophosphatidylcholine (LPC) to induce the acrosome reaction in the capacitated spermatozoids [19]. After this period, smears stained with fluo- 
rescein-conjugated Pisumsativum agglutinin (FITC-PSA) were prepared and analyzed under an epifluorescence microscope. Cells (200) were counted and the percentage of spermatozoa with a green-stained acrosomal region (a positive acrosome reaction), was estimated.

\subsection{Statistical Analysis}

The size of the protein bands was subjected to analysis of variance and differences between groups were compared with a t-test, setting a significance level of $P<0.05$. The percentage of cells exhibiting a positive acrosome reaction between treatments was compared by chi-square test. The level of significance set was $P<$ 0.05 .

\section{Results}

\subsection{Western Blot}

The use of a monoclonal anti-ACE antibody revealed at leastone $100-\mathrm{kDa}$ protein band in the spermatozoid suspension from Nelore bulls.

The pattern of the pre- (Figure 1(a)) and post-cryopreservation (Figure 1(b)) protein bands in semen with the anti-ACE antibody showed that the amount of protein was reduced following cryopreservation.

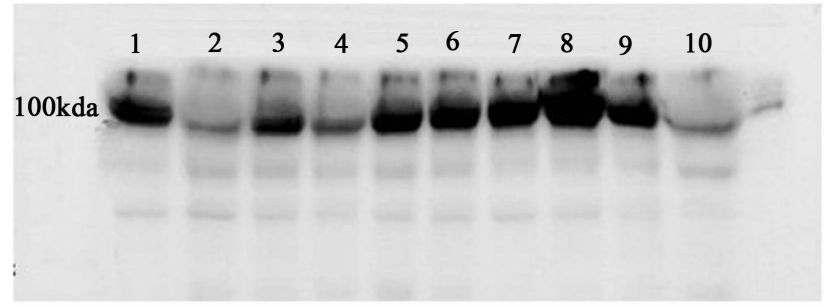

(a)

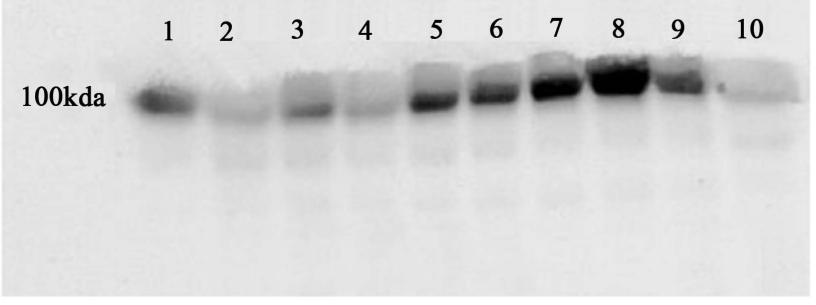

(b)

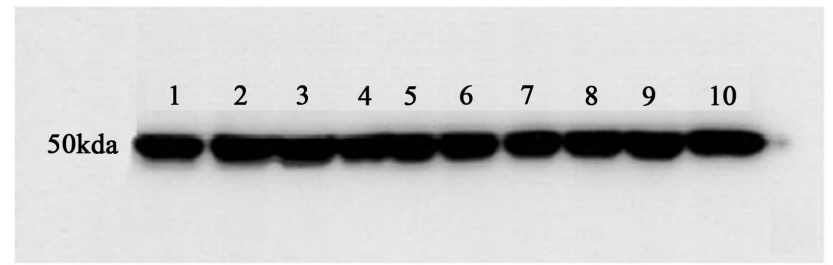

(c)

Figure 1. Immunodetection reactions of ACE in the semen of Nelore bulls, pre- (a) and post-cryopreservation (b). Immunodetection of $\beta$-tubulin protein (c). Western blot analysis with anti-ACE monoclonal antibody and anti- $\beta$-tubulin. Each column represents a different bull. 
Western blot analysis with an anti- $\beta$-tubulin antibody (Figure $1(\mathrm{c})$ ) showed that the same amount of protein was used in the samples evaluated.

Figure 1 shows a single picture of an X-ray film; the three nitrocellulose membranes were placed together in order to avoid differences in the intensity of protein bands following exposure to luminol for different times.

The freezing process increased the number of pixels in the ACE bands of samples from the 10 Nelore bulls after cryopreservation $(P<0.05)$, indicating reduced protein expression of this enzyme as a result of the protocol used (Figure 2). The amount of protein in the samples from each animal was similar, as demonstrated by the number of pixels in the $\beta$-tubulin bands for samples from the 10 bulls (Figure 3).

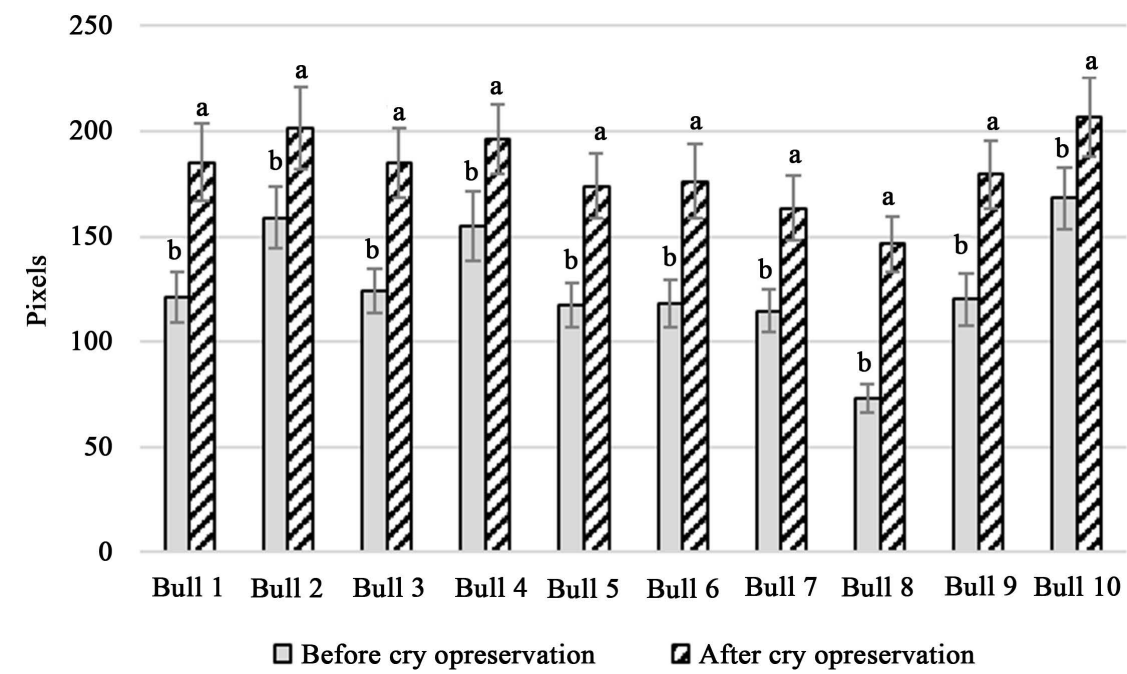

Figure 2. Number of pixels in the ACE bands, as detected by western blot, for 10 Nelore bulls, pre- and post-cryopreservation, calculated by Image J Software 1.40. The lower the number of pixels, the greater the amount of ACE. Different letters represent a significant difference, determined by the $\mathrm{t}$ test $(P<0.05)$.

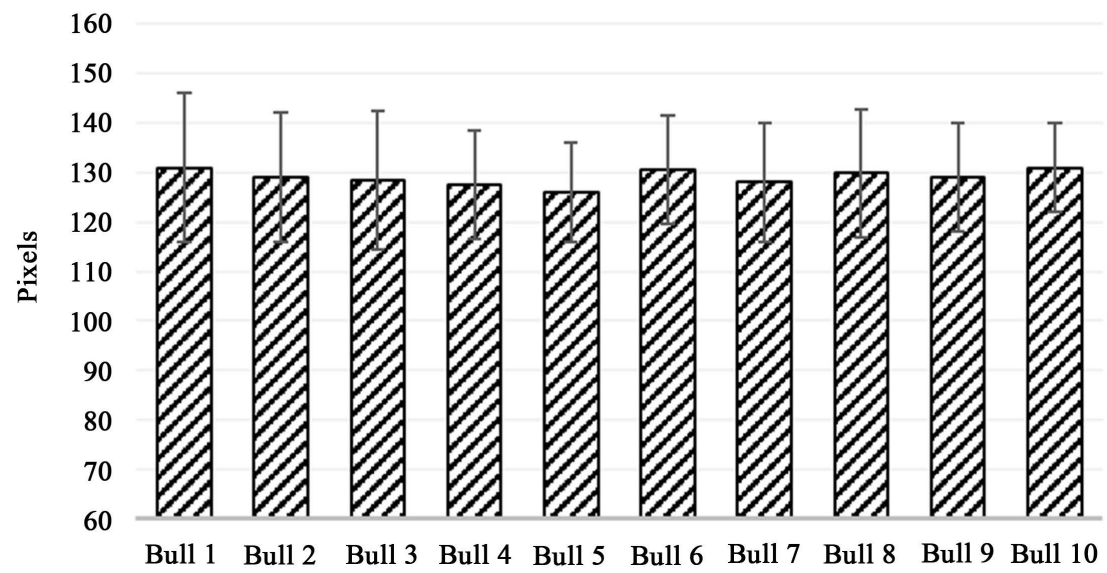

Figure 3. Number of pixels in the $\beta$-tubulin bands, as detected by western blot, of the spermatozoa of 10 Nelore bulls, calculated by Image J Software 1.40. The lower the number of pixels, the greater the amount of $\beta$-tubulin. 


\subsection{Induction of the Acrosome Reaction in the Capacitated Spermatozoids}

Following induction of the acrosome reaction, the smears were analyzed under an epifluorescence microscope. The estimated percentage of spermatozoa with a positive acrosome reaction was $83 \%$ in the Heparin group (Figure $4(a)$ ), $11 \%$ in the control group (Figure 4(b)), and 13\% in the captopril + heparin group (Figure 4(c)). There was a significant difference between the results obtained for the heparin group and those obtained for the other two groups $(P<0.05)$; however, there was no difference between the control and heparin + captopril groups $(P>0.05)$.

\section{Discussion}

Western blot analysis with a monoclonal anti-ACE antibody revealed a single protein band with a molecular mass of approximately $100 \mathrm{kDa}$ in extracts prepared from the semen of sexually mature Nelore bulls. The molecular mass of the protein band was consistent with that reported for tACE, between 90 and $110 \mathrm{kDa}$ [4]. This result was consistent with the findings of other studies in different species: rabbit [20], pig [21], human [22], mouse [23], sheep [24], and Holsteinbulls [15].

Equal amounts of protein were loaded from each animal, as confirmed by the immunodetection of $\beta$-tubulin (Figure $1(\mathrm{c})$ ). This suggests that differences in the intensity of protein bands among animals (Figure 1(a) and Figure 1(b)) are intrinsic to each individual. Other proteins present in the plasma membrane of sperm or in seminal plasma, are correlated with fertility in bulls, either in a proportional manner, such as osteopontin (OPN), BSP $30 \mathrm{kDa}$, phospholipase A2, heparin binding proteins, and P25b [25] [26], or in an inversely proportional manner, such as spermadhesinZ13 and clusterin [26] [27]. Thus, if a visual difference is found in the amount of ACE protein among the animals evaluated is also observed in fertility and/or seminal freezing, ACE could be a fertility marker.

The location of tACE in sperm varies between species, and disagreement exists among researchers investigating the same species. Nikolaeva et al. [28], in a

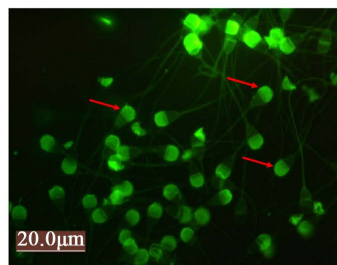

(a)

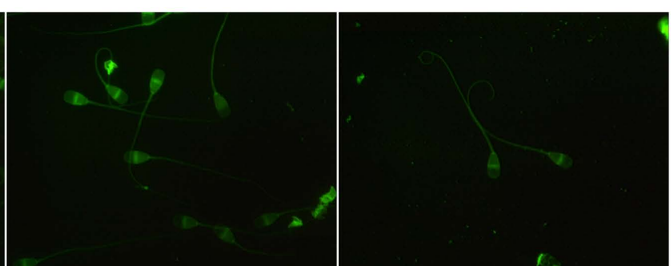

(b) (c)

Figure 4. Smears stained with FITC PSA were analyzed under an epifluorescence microscope to estimate the percentage of spermatozoa with a positive acrosome reaction. (a) heparin; (b) Control; and (c) Captopril + heparin. 400× magnification. Green coloration in the acrosomal region indicates a positive acrosome reaction (red arrow). 
study with human sperm, found tACE in the post-acrosomal region and in the midpiece, while Köhn et al. [29] described its presence in the same species, in the entire sperm head (acrosome, equatorial segment, post-acrosomal region), midpiece, and flagellum, and Foresta et al. [30] in cytoplasmic droplets.

In pigs, tACE was detected in spermatids and cytoplasmic droplets of epidydimal sperm [21]. In an experiment with rabbits, Brentjens et al. [31] found tACE in spermatids and cytoplasmic droplets, consistent with findings in pigs. The location of this enzyme inspermatozoa of rodents was described by Metayer et al. [32], and in both rats and mice, was located in the midpiece and the initial part of the flagellum.

Changes in the structure of the plasma membrane (PM) occur during the freeze/thaw of semen, which can lead to cold thermal shock, loss of proteins on the spermatozoa surface, and damage to the sperm cell, such as rupture of the PM and, consequently, death of the spermatozoa [33] [34]. Several seminal proteins are related to semen freezability, such as bovine acidic seminal fluid protein (aSFP), albumin, OPN, sperm binding proteins (BSP) A1 and A2, and P25b [25] [35]. In the present study, the expression of tACE was reduced by approximately $70 \%$ (from 2923 to 938.5$)(P<0.05)$ after semen cryopreservation, which is similar to the results found by Nauc and Manjunath [36], who observed a 70\% to $80 \%$ reduction in the concentration of BSP proteins bound to the PM after the cryopreservation of bovine semen.

As with tACE, BSP A1 and A2 are related to sperm capacitation, and sperm protein P25b is involved in the fusion of gametes [37] [38], Although the exact role of tACE in these processes is unknown [9], given that this enzyme is anchored to the PM [1], like BSP and P25b, reorganization of PM components during freezing may explain the reduced amount of tACE detected in sperm. Like the proteins listed above, which are important for bull fertility, the quantity of tACE in bovine ejaculate could be considered an important factor in the choice of a breeder for the freezing of semen, since after the cryopreservation process, there is reduced tACE, along with other proteins [34], and their presence is indispensable for the fertilization of the egg [8] [39].

In an experiment carried out comparing ACE activity in rooster, buffalo, and bull semen by spectrophotometry (using hippuryl-L-histidyl-L-leucine, as a substrate), Mohan et al. [40] reported that ACE activity in the bird was not altered by cold shock. However, in both buffaloes and bulls, there was a decrease in the amount of ACE in the spermatozoa and an increase in seminal plasma. This was attributed to the loss of enzyme from the sperm cell PM, and its accumulation in plasma due to the cold thermal shock experienced by sperm during the freezing process. It is probable that the same occurred in our study, since there was a reduction in the amount of ACE in the spermatozoa of the Nelore bulls after cryopreservation; however, the amount of $\mathrm{ACE}$ in the plasma following cryopreservation, was not measured.

Mammalian sperm undergoes physiological changes during its trajectory in 
the reproductive system of the female, termed sperm capacitation and acrosome reaction, and these events are necessary for the fertilization of the egg [10]. Ball et al. [13] suggested that ACE plays an important role in capacitation processes and in the acrosome reaction in sperm, although this mechanism has not been fully elucidated. In this experiment, the heparin group displayed a higher percentage of capacitated sperm, and sperm with a positive acrosome reaction, compared with the control and heparin + captopril groups $(83 \%, 11 \%$, and $13 \%$, respectively) $(P<0.05)$, indicating that ACE inhibition by captopril $(10 \mu \mathrm{M})$ affected capacitation and, consequently, the acrosome reaction. The percentage of sperm with a positive acrosome reaction in the captopril group was similar to that in the control group, with a spontaneous reaction $(P>0.05)$. These results are similar to those found in Holstein bulls [15].

Costa and Thundathil [15] showed that spermatozoa and seminal plasma of Holstein bulls possess ACE activity, through the hydrolysis of furanylacryloyl-L-phenylalanylglycylglycine (FAPGG) to furanylacryloyl-L-phenylalanyl and glycyl-glycine. Captopril $(10 \mu \mathrm{M})$ was efficient in inhibiting the activity of tACE and, consequently, sperm capacitation; therefore, a smaller percentage of cells had a positive acrosome reaction, as observed in the present study.

Gur et al. [10] found angiotensin II (AT1) receptors only in the tail of noncapacitated sperm; however, in capacitated cells, AT1 was found in the tail and periacrosomal regions. Those authors successfully induced the acrosome reaction in vitro using angiotensin II in the presence of calcium. It is probable that the amount of ACE inhibitor used in our experiment was able to reduce the conversion of angiotensin I to angiotensin II, which seems to play an important role in the activation of the acrosome reaction via the AT1 receptor, which would explain the lower percentage of capacitated spermatozoa in the heparin + captopril group.

\section{Conclusion}

tACE can be found in the sperm of Nelore bulls. The cryopreservation process leads to a decrease in the intensity of the bands of this enzyme, and the inactivation of tACE reduces the ability of sperm to undergo the acrosome reaction.

\section{Acknowledgements}

This work was supported by the Conselho Nacional de Desenvolvimento Científico e Tecnológico-CNPq (Processo: 470561/2012-2).

\section{Conflicts of Interest}

None of the authors of this paper has a financial or personal relationship with other people or organizations that could inappropriately influence or bias the content of the paper.

\section{References}

[1] Corvol, P., Williams, T.A. and Soubrier, F. (1995) [18] Peptidyl Dipeptidase A: An- 
giotensin I-Converting Enzyme. Methods in Enzymology, 248, 283-305. https://doi.org/10.1016/0076-6879(95)48020-X

[2] Sabeur, K., Vo, A.T. and Ball, B.A. (2001) Characterization of Angiotensin-Converting Enzyme in Canine Testis. Reproduction, 122, 139-146.

https://doi.org/10.1530/rep.0.1220139

[3] Henriques, G.S., Hirata, M.H. and Cozzolino, S.M.F. (2003) Recent aspects of zinc absorption and bioavailability and correlations with physiology of the testicular Angiotensin-Converting Enzyme. Revista de Nutrição/ Brazilian Journal of Nutrition, 16, 333-345. https://doi.org/10.1590/S1415-52732003000300011

[4] Corvol, P., Eyries, M. and Soubrier, F. (2004) Peptidyl Dipeptidase A: Angiotensin I-Converting Enzyme. In: Barret, A.J., Rawlings, N. and Woessner, J., Eds., Handbook of Proteolytic Enzymes, Elsevier Science Publishers, Amsterdam, 332-349.

[5] Deguchi, E., Tani, T., Watanabe, H., Yamada, S. and Kondoh, G. (2007) Dipeptidase-Inactivated tACE Action in Vivo: Selective Inhibition of Sperm-Zona Pellucida Binding in the Mouse. Biology of Reproduction, 77, 794-802. https://doi.org/10.1095/biolreprod.107.060004

[6] Velletri, P.A., Aquilano, D.R., Brucknick, E., Tsai-Morris, C.H., Dufau, M.L. and Lovemberg, W. (1985) Endocrinological Control and Cellular Localization of Rat Testicular Angiotensin-Converting Enzyme (EC 3.4. 15.1). Endocrinology, 116, 2516-2522. https://doi.org/10.1210/endo-116-6-2516

[7] Hagaman, J.R., Moyer, J.S., Bachman, E.S., Sibony, M., Magyar P.L., Welch, J.E., Smithies, O., Krege, J.H. and O'Brien, D.A. (1998) Angiotensin-Converting Enzyme and Male Fertility. Proceedings of the National Academy of Sciences of the United States of America, 95, 2552-2557. https://doi.org/10.1073/pnas.95.5.2552

[8] Kondoh, G., Tojo, H., Nakatani, Y., Komazawa, N., Murata, C., Yamagata, K., Maeda, Y., Kinoshita, T., Okabe, M., Taguchi, R. and Takeda, J. (2005) Angiotensin-Converting Enzyme Is a GPI-Anchored Protein Releasing Factor Crucial for Fertilization. Nature Medicine, 11, 160-166. https://doi.org/10.1038/nm1179

[9] Köhn, F.M., Miska, W. and Schill, W.B. (1995) Release of Angiotensin-Converting Enzyme (ACE) from Human Spermatozoa during Capacitation and Acrosome Reaction. Journal of Andrology, 6, 259-265.

[10] Gur, Y., Breitbart, H., Lax, Y., Rubinstein, S. and Zamir, N. (1998) Angiotensin II Induces Acrosomal Exocytosis in Bovine Spermatozoa. American Journal of Physiology, 275, 87-93. https://doi.org/10.1152/ajpendo.1998.275.1.E87

[11] Shibahara, H., Kamata, M., Hu, J., Nakagawa, H., Obara, H., Kondoh, N., Shima, H. and Sato, I. (2001) Activity of Testis Angiotensin-Converting Enzyme (ACE) in Ejaculated Human Spermatozoa. International Journal of Andrology, 24, 295-299. https://doi.org/10.1046/j.1365-2605.2001.00301.x

[12] Heder, G., Siems, W., Mudra, K., Nehring, H., Seiffert, I. and Jentzsch, K.D. (1990) Occurrence and Potential Importance of Angiotensin-Converting Enzyme in Semen of Boars. Andrologia, 22, 437-443. https://doi.org/10.1111/j.1439-0272.1990.tb02024.x

[13] Ball, B.A., Gravance, C.G., Wessel, M.T. and Sabeur, K. (2003) Activity of Angiotensin-Converting Enzyme (ACE) in Reproductive Tissues of the Stallion and Effects of Angiotensin II on Sperm Motility. Theriogenology, 59, 901-914. https://doi.org/10.1016/S0093-691X(02)01127-5

[14] Vanha-Perttula, T., Mather, J.P., Bardin, C.W., Moss, S.B. and Bellve, A.R. (1985) Localization of the Antigotensin-Converting Enzyme Activity in Testis and Epidi- 
dymis. Biology of Reproduction, 33, 870-877. https://doi.org/10.1095/biolreprod33.4.870

[15] Costa, D.S. and Thundathil, J.C. (2012) Characterization and Activity of Angiotensin-Converting Enzyme in Holstein Semen. Animal Reproduction Science, 133, 35-43. https://doi.org/10.1016/j.anireprosci.2012.06.009

[16] Schenk, J.L., Suh, T.K., Cran, D.G. and Seidel Jr., G.E. (1999) Cryopreservation of Flow-Sorted Bovine Spermatozoa. Theriogenology, 52, 1375-1391. https://doi.org/10.1016/S0093-691X(99)00224-1

[17] Newton, L.D., Kastelic, J., Wong, B., Van Der Hoorn, F. and Thandanthil, J. (2009) Elevated Testicular Temperature Modulates Expression Patterns of Sperm Proteins in Holstein Bulls. Molecular Reproduction and Development, 76, 109-118. https://doi.org/10.1002/mrd.20934

[18] Peknicova, J., Pexidrova, M., Kubatova, A., Koubek, P., Tepla, O., Sulimenko, T. and Draber, P. (2007) Expression of Beta-Tubulin Epitope in Human Sperm with Pathological Spermiogram. Fertility and Sterility, 88, 1120-1128. https://doi.org/10.1016/j.fertnstert.2006.12.070

[19] Parrish, J.J., Susko-Parrish, J., Winer, M.A. and First, N.L. (1988) Capacitation of Bovine Sperm by Heparin. Biology of Reproduction, 38, 1171-1188.

https://doi.org/10.1095/biolreprod38.5.1171

[20] El-Dorry, H.A., Bull, H.G., Iwata, K., Thornberry, E.H. and Soffer, R.L. (1982) Molecular and Catalytic Properties of Rabbit Testicular Dipeptidylcarboxypeptidase. Journal of Biological Chemistry, 257, 14128-14133.

[21] Yotsumoto, H., Sato, S. and Shibuya, M. (1984) Localization of Angiotensin Converting Enzyme (Dipeptidylcarboxypeptidase) in Swine Sperm by Immunofluorescence. Life Sciences, 35, 1257-1261. https://doi.org/10.1016/0024-3205(84)90096-1

[22] Ehlers, M.R.W., Maeder, D.L. and Kirsch, R.E. (1986) Rapid Affinity Chromatographic Purification of Human Lung and Kidney Angiotensin-Converting Enzyme with the Novel N-Carboxyalkyl Dipeptide Inhibitor N-[1(S)-Carboxy-5-Aminopentyl]Glycylglycine. Biochimica et Biophysica Acta (BBA)_General Subjects, 883, 361-372. https://doi.org/10.1016/0304-4165(86)90329-6

[23] Langford, K.G., Zhou, Y., Russell, L.D., Wilcox, J.N. and Bernstein, K. (1993) Regulated Expression of Testis Angiotensin-Converting Enzyme during Spermatogenesis in Mice. Biology of Reproduction, 48, 1210-1218. https://doi.org/10.1095/biolreprod48.6.1210

[24] Gatti, J.L., Druart, X., Guerin, Y., Dacheux, F. and Dacheux, J.L. (1999) A 105- to 94-Kilodalton Protein in the Epididymal Fluids of Domestic Mammals Is Angiotensin I-Converting Enzyme (ACE); Evidence That Sperm Are the Source of ACE. Biology of Reproduction, 60, 937-945. https://doi.org/10.1095/biolreprod60.4.937

[25] Parent, S., Lefièvre, L., Brindle, Y. and Sullivan, R. (1999) Bull Subfertility Is Associated with Low Levels of a Sperm Membrane Antigen. Molecular Reproduction and Development, 52, 57-65. https://doi.org/10.1002/(SICI)1098-2795(199901)52:1<57::AID-MRD8>3.0.CO;2-U

[26] Moura, A.A., Koc, H., Chapman, D.A. and Killian, G.J. (2006) Identification of Proteins in the Accessory Sex Gland Fluid Associated With Fertility Indexes of Dairy Bulls: A Proteomic Approach. Journal of Andrology, 27, 201-211. https://doi.org/10.2164/jandrol.05089

[27] Ibrahim, N.M., Gilbert, G.R., Loseth, K.J. and Crabo, B.G. (2000) Correlation between Clusterin-Positive Spermatozoa Determined by Flow Cytometry in Bull Se- 
men and Fertility. Journal of Andrology, 21, 887-894.

[28] Nikolaeva, M.A., Balyasnikova, I.V., Alexinskaya, M.A., Metzger, R., Franke, F.E., Albrecht, R.F., Kulakov, V.I., Sukhikh, G.T. and Danilov, S.M. (2006) Testicular Isoform of Angiotensin I-Converting Enzyme (ACE, CD143) on the Surface of Human Spermatozoa: Revelation and Quantification Using Monoclonal Antibodies. Am. Journal of Reproductive Immunology, 55, 54-68. https://doi.org/10.1111/j.1600-0897.2005.00326.x

[29] Köhn, F.M, Dammshauser, I., Neukamm, C., Renneberg, H., Siems, W.E., Schill, W.B. and Aumuller, G. (1998) Ultrastructural Localisation of Angiotensin-Converting Enzyme in Ejaculated Spermatozoa. Human Reproduction, 13, 604-610. https://doi.org/10.1093/humrep/13.3.604

[30] Foresta, C., Indino, M., Manoni, F. and Scandellari, C. (1987) Angiotensin-Converting Enzyme Content of Human Spermatozoa and Its Release during Capacitation. Fertility and Sterility, 47, 1000-1003. https://doi.org/10.1016/S0015-0282(16)59236-X

[31] Brentjens, J.R., Matsuo, S., Andres, G.A., Calwell, P.R.B. and Zomboni, L. (1986) Gametes Contain Angiotensin-Converting Enzyme (Kininase II). Experientia, 42, 399-402. https://doi.org/10.1007/BF02118626

[32] Metayer, S., Dacheux, F., Dacheux, J.L. and Gatti, J.L. (2002) Germinal Angiotensin I-Converting Enzyme Is Totally Shed From the Rodent Sperm Membrane during Epididymal Maturation. Biology of Reproduction, 67, 1763-1767. https://doi.org/10.1095/biolreprod.102.006684

[33] Lasso, J.L., Noiles, E.E., Alvarez, J.G. and Storey, B.T. (1994) Mechanism of Superoxide Dismutase Loss from Human Sperm Cells during Cryopreservation. Journal of Andrology, 15, 255-265.

[34] Jobim, M.I.M., Gregory, R.M. and Mattos, R.C. (2009) Seminal Plasma Proteins Related to Bovine Semen Freezability. Revista Brasileira de Reprodução Animal, 6, 25-31.

[35] Jobim, M.I.M., Oberst, E.R., Salbego, C.G., Souza, D.O., Wald, V.B., Tramontina, F. and Mattos, R.C. (2004) Two-Dimensional Polyacrylamide Gel Electrophoresis of Bovine Seminal Plasma Proteins and Their Relation with Semen Freezability. Theriogenology, 61, 255-266. https://doi.org/10.1016/S0093-691X(03)00230-9

[36] Nauc, V. and Manjunath, P. (2000) Radioimmunoassays for Bull Seminal Plasma Proteins (BSP-A1/-A2, BSP-A3, and BSP-30-Kilodaltons), and Their Quantification in Seminal Plasma and Sperm. Biology of Reproduction, 63, 1058-1066. https://doi.org/10.1095/biolreprod63.4.1058

[37] Berube, B. and Sullivan, R. (1994) Inhibition of in Vivo Fertilization by Active Immunization of Male Hamsters against a $26-\mathrm{kDa}$ Sperm Glycoprotein. Biology of Reproduction, 51, 1255-1263. https://doi.org/10.1095/biolreprod51.6.1255

[38] Thérien, I., Soubeyrand, S. and Manjunath, P. (1998) Major Proteins of Bovine Seminal Plasma Modulate Sperm Capacitation by High-Density Lipoprotein. Biology of Reproduction, 57, 1080-1088. https://doi.org/10.1095/biolreprod57.5.1080

[39] Corvol, P. (2005) ACE Sets up Fertilization. Nature Medicine, 11, 118-119. https://doi.org/10.1038/nm0205-118

[40] Mohan, J., Moudgal, R.P., Pandaland, J.N. and Mohan, G. (1992) Effects of Cold Shock Treatment on Angiotensin-Converting Enzyme Activity and on Semen Characteristics in Roosters and Bulls. Theriogenology, 37, 1147-1154.

https://doi.org/10.1016/0093-691X(92)90111-4 